Bolm Inst. oceanogr., S Pau1o, 23:33-46, 1974

\title{
OBSERVATIONS ON STAGES OF UPWELLING IN THE REGION OF CABO FRIO (BRAZIL) AS CONDUCTED BY CONTINUOUS SURFACE TEMPERATURE AND SALINITY MEASUREMENTS*
}

Received September 26, 1972

Y. IKEDA, L.B. de MIRANDA \& N.J. ROCK**

Instituto oceanogräfico da Universidade de são Pauzo

SYNOPSIS

\begin{abstract}
A brief outline is given of the results of surface temperature and salinity to the west and southwest of Cabo Frio obtained in August of 1971 with a continuous recording Thermo-Salinograph (Bissett-Berman, Mode $16600 \mathrm{~T}$ ). A rapid change was observed in the field distribution of temperature from $21.5-21.9^{\circ} \mathrm{C}$ to $15-21^{\circ} \mathrm{C}$, and similary change in the distribution of salinity from 34.1-35.0\% 00 to 35.3-36.0\% time scale of seven days. The changes were accredited to the process of upwelling at the coastal region under the influence of $E$ and NE winds. The occurrence of a surface counter-current moving upwind was detected. This anomaly, not explained on the basis of the Ekman's classical theory, was qualitatively explained as the result of a horizontal divergence in the wind-stress field.
\end{abstract}

\section{INT RODUCTION}

The occurrence of upwelling in the region of Cabo Frio has been studied by several workers (Emílsson, 1959; Silva, 1960; Emílsson, 1961; Silva \& Rodrigues, 1966; Mascarenhas, Miranda \& Rock, 1971; Magliocca \& Miranda, in press). All of these previous studies have used classical water-sampling techniques with intervals between stations ranging from 10 to $40 \mathrm{~nm}$. The present authors believe that the results obtained are the first of their kind in Brazil, both in speed of coverage (less than one day c.f. two days normally taken for hydrographic stations) and in the detail obtained from the records. It is almost certain that without continuous sensing, a major part of the phenomenon would have been missed.

* This work was presented at the United Nations Panel Meeting on the Establishment and Implementation of Research Programmes in Remote Sensing November 29-December 10/1971 - Conse1ho Nacional de Pesquisas - Instituto de Pesquis as Espaciais em São José dos Campos, SP. Brasil.

** Visiting Professor at the Instituto oceanogräfico da Universidade de São Paulo on a Conselho Nacional de Pesquisas (CNPq) grant.

PUBL. NO"354 DO INST. OCEAN. DA USP. 
The measurements were taken in a supporting role to supply "ground truth" data for an air-borne remote sensing program in oceanography with the Brazilian Institute of Space Research (Instituto de Pesquisas Espaciais INPE).

\section{INSTRUMENT AND DATA}

The temperature was sensed by a pair of thermistor probes installed in the cooling-water intake of the Institute's ship (R/V "Prof.W. Besnard"), situated at a distance of about $3 \mathrm{~m}$ below the surface. For salinity, a junction with the cooling-water intake pipe takes water from the cooling system, circulates it through an air-bubble extracting column, whence it passes around the salinity sensor head. Rough weather during the cruise (wind force 6 to 7 in the Beaufort scale) caused irregular fluctuations in the salinity trace due to excessive aeration in the cooling-water.

The sensors form a part of separate wheatstone bridges, and the salinity sensor has an additional thermistor temperature compesation circuit. The signals are so calibrated that they record temperature $\left( \pm 0.1^{\circ} \mathrm{C}\right)$ and salinity $\left( \pm 0.03^{\circ} / 00\right)$ directly on an $X_{1}, X_{2}$ strip chart recorder. The temperature scale is divided into five overlapping ranges each of $10^{\circ} \mathrm{C}$ full scale deflection (f.s.d.), covering the temperature interval $-2{ }^{\circ} \mathrm{C}$ to $36^{\circ} \mathrm{C}$; and the salinity scale into six overlapping ranges each of $2 \%$ (f.s.d.) covering the interval $28 \%$ to $37.5 \%$, with two additional coarse $(20 \%$ oo $-30 \%$ and $28 \% 00-$ $\left.38^{\circ} / 00\right)$.

For greater details of the equipment installation the reader is referred to Almeida, Mascarenhas \& Ikeda (1971).

\section{TECHNIQUE}

Four separate mappings of the area were carried out using on ly the continuous Thermo-Salinograph data and, for this reason, are a good approximation to a synoptic picture of the surface distributions. Temperature and salinity values were read at ten minutes intervals and ships position, obtained from radar fixes on prominent coastal features, was plotted at half hourly intervals. Field distributions of temperature and salinity were plotted on board ship, as guidelines to further sampling.

Fortunate1y, the four continuous mappings more or less coincided in time to the flights over the area, of the Navy helicopter equipped with a Precision Radiation Thermometer (PRT-5), for sensing the temperature of the air-sea 
boundary. Two hydrographic surveys of the area were also carried out to check the performance of the instrument and to obtain data from the subsurface layers. The non-stationarity of the field distributions over the period during which the hydrographic stations were effected, produces a non-realistic idea of the instantaneous field distributions. Therefore, due to the disparity between the hydrographic data and that obtained from the continuous recording, the former has been ommitted from this presentation.

RESULTS

\section{a. ACCURACY}

A sample comparison of the continuous temperature and salinity records with standard measurements at hydrographic stations is presented in Figure 1. The discontinuities in the traces shown are caused by the drifting of the ship, with respect to horizontal temperature and salinity gradients while on station. The position of the dot indicates the direct measurement, and its size in this figure represents the expected error of the continuous ThermoSalinograph traces. The temperatures and salinities as read at the time of the hydrographic cast (sample taken at $3 \mathrm{~m}$ depth) corresponded closely to the direct measurements, within the accuracy of the apparatus $\left( \pm 0.1^{\circ} \mathrm{C}\right.$ and $\pm 0.03 \%$, respectively). Consequently the continuous data was utilized without any corrections.

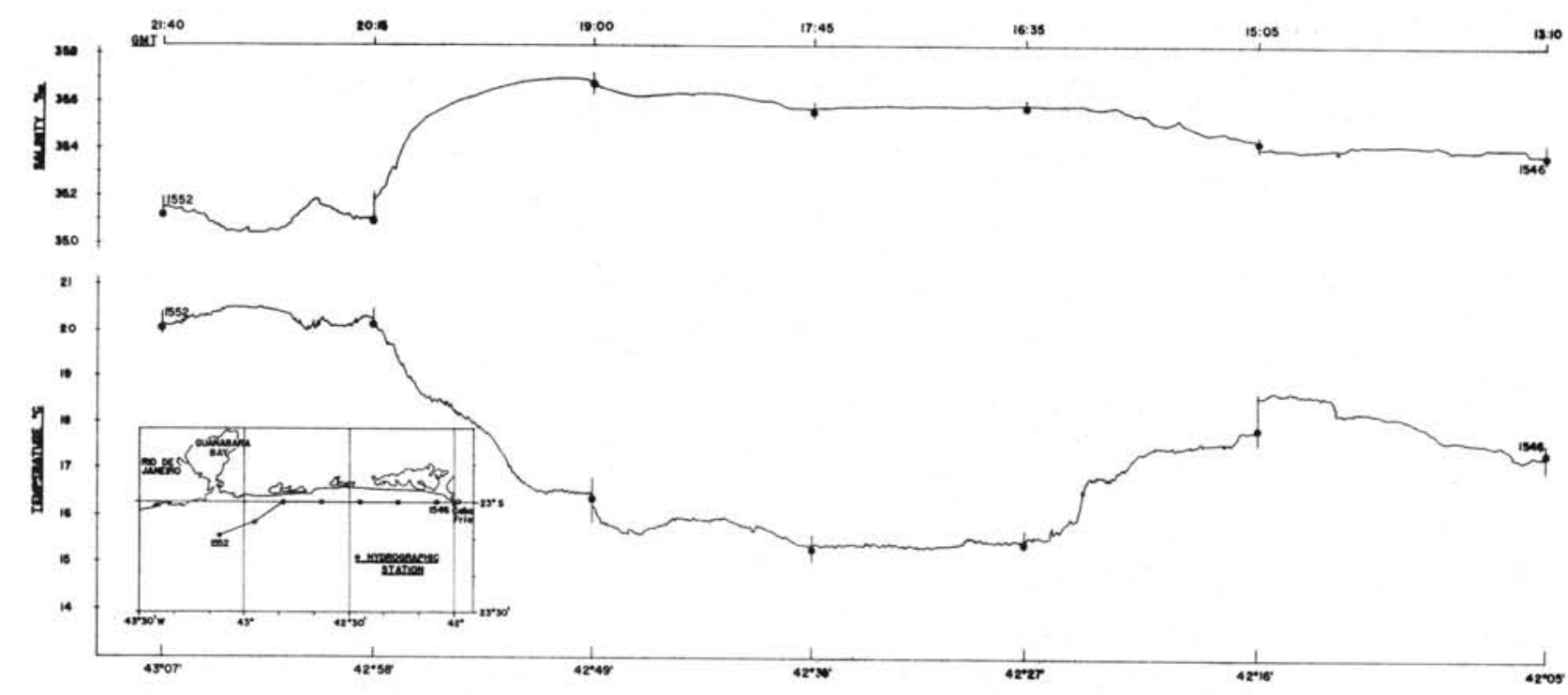

Fig. 1 - Comparison between standard hydrographic data and continuous graphic recording. 


\section{b. DISTRIBUTIONS OF TEMPERATURE AND SALINITY}

Pass $1(03: 30$ h 08/18/71 - 07:30 h 08/19/71) - During the first pass through the region, whilst searching for distinctive horizontal temperature and salinity structure between the coast and the Brazil Current, a 1 arge part of the coast northeast of Cabo Frio was also sampled. The situation was quite uniform over a large area with surface temperatures ranging between $21.5^{\circ} \mathrm{C}-$ $21.9^{\circ} \mathrm{C}$ and surface salinities between $34.1 \% / 00-35.0 \%$, indicating the presence of a light $\left(\sigma_{t}<24.0\right)$ coastal type of water mass (Figs 2-3).

At approximately 19:00 h on the 18th of August a remarkable change in the wind-speed occurred, starting to freshen ( $>\mathrm{m} / \mathrm{s})$ from $N E$.

Pass $2(01: 30$ h 08/20/71 - 10:00 h 08/21/71) - The second pass consisted of two east-west transects at an approximate distance of $8 \mathrm{~nm}$ and $4 \mathrm{~nm}$ from the coast (Figs 4-5, respectively). In the farthest section from the coast (Fig. 4), the first evidence of surface temperature be 1 ow $19^{\circ} \mathrm{C}$ and salinities above $35.2 \%$ is seen, after a time-1apse of about 34 hours since the wind started to blow. Of special interest are the fluctuations of temperature and salinity $\left(0.25^{\circ} \mathrm{C}, 0.1 \% \mathrm{o}\right)$, which suggest a finger-like structure in the horizontal, associated with spatial scales of less than $1 \mathrm{~nm}$. This structuring persisted for some $20 \mathrm{~nm}$.

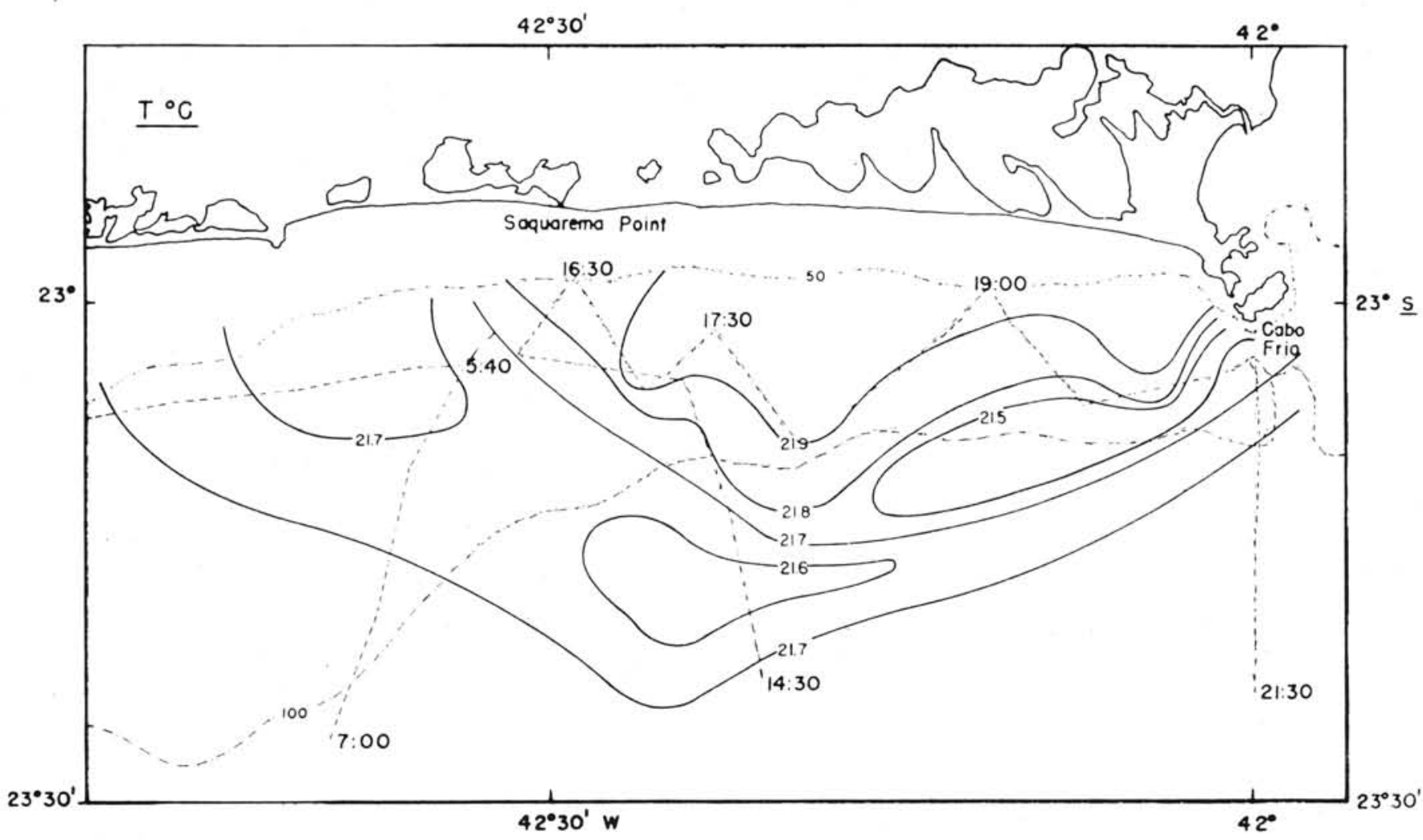

Fig. 2 - Temperature distribution on the surface (pass 1). 


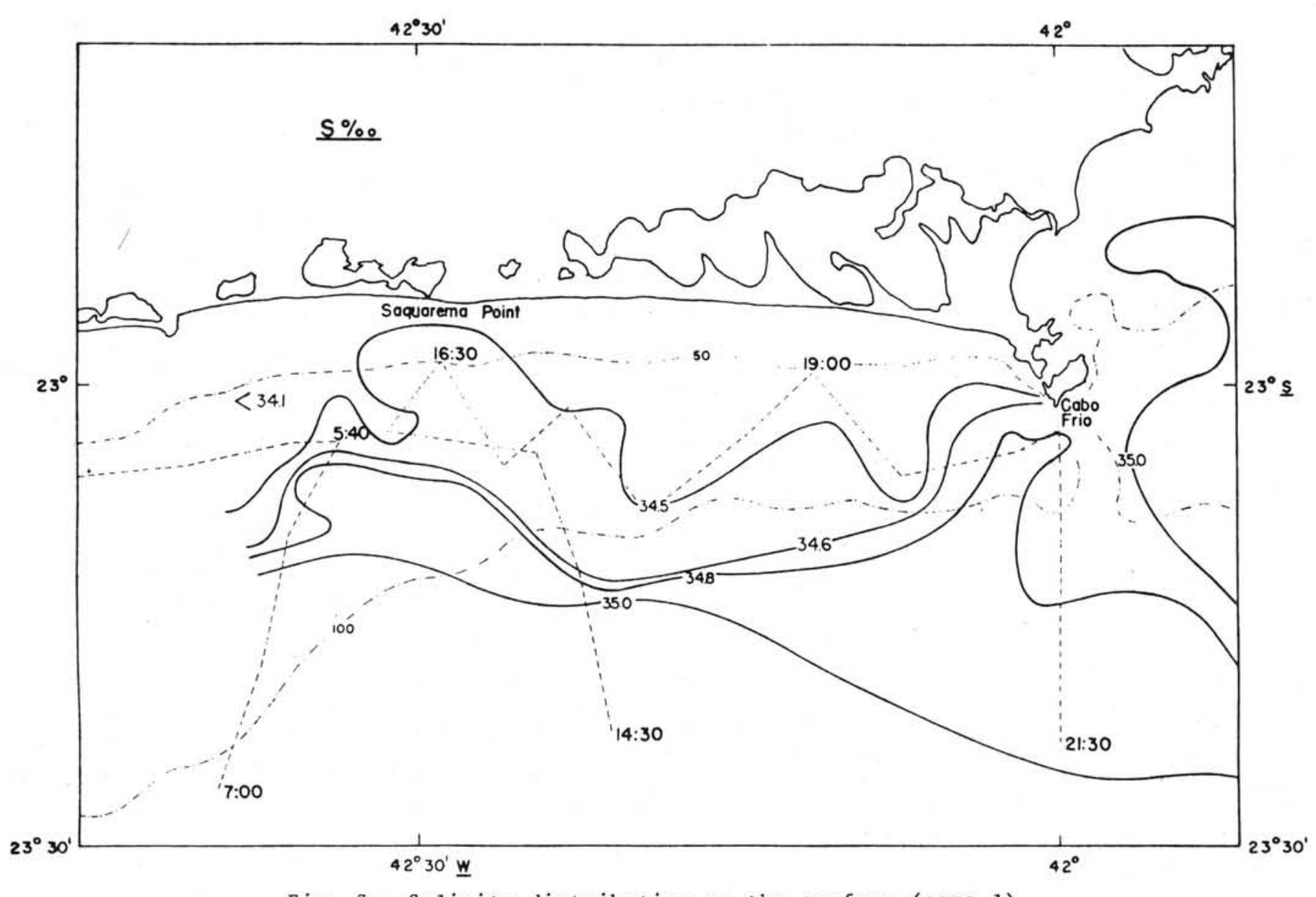

Fig. 3 - Salinity distribution on the surface (pass 1).

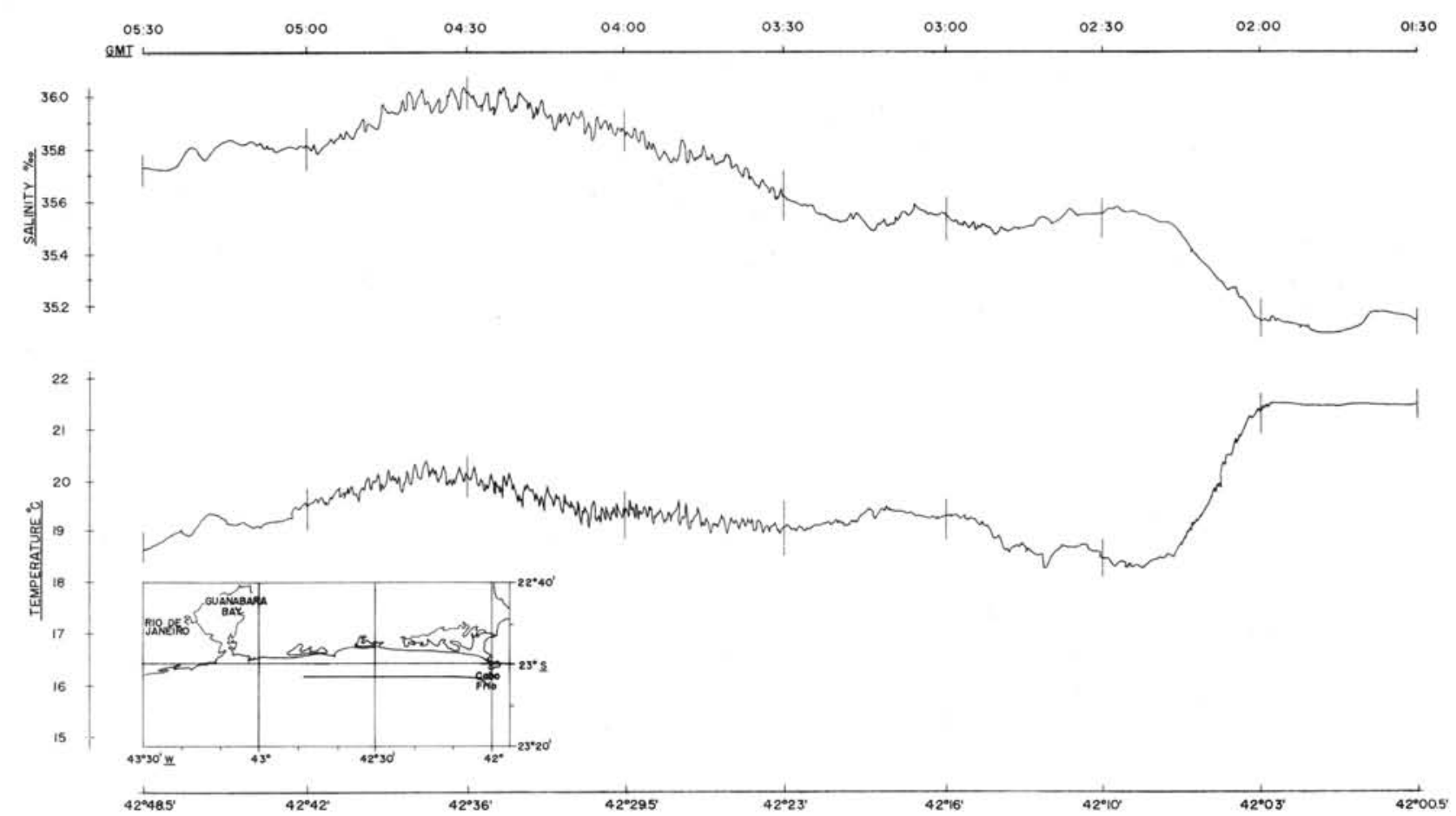

Fig. 4 - Temperature and salinity traces on the surface (pass 2, section 1). 
Closer to the coast (Fig. 5) even lower temperatures $\left(\mathrm{T}<17^{\circ} \mathrm{C}\right.$ ) and higher salinities $\left(\mathrm{S}>35.6^{\circ} / \mathrm{oo}\right)$ were found. Over a band of $25 \mathrm{~nm}\left(42^{\circ} 30^{\prime} \mathrm{W}-42^{\circ} 06^{\prime} \mathrm{W}\right)$ the surface water hand a distinctive characteristics of Subtropical Shelf Water (STSW) $\left(12{ }^{\circ} \mathrm{C}-15^{\circ} \mathrm{C} ; 35.1 \% 0-35.5^{\circ} / 00\right)$, which generally constitutes the principal water mass of the upwelling process (Mascarenhas, Miranda \& Rock, 1971).

An anomalous peak $P$ (Fig. 5) in both temperature $\left(+1.0^{\circ} \mathrm{C}\right)$ and salinity $\left(-0.5^{\circ} / 00\right)$ occurs at position $23^{\circ} 00^{\prime} \mathrm{s} ; 042^{\circ} 08^{\prime} \mathrm{W}$ which, if real, represents a less dense water mass of no more than $100 \mathrm{~m}$ extent. If caused by an electrical fault then there is no similar recurrence in 200 hrs of recording, and temperature and salinity ought to be equally affected. Consequent ly the origin of such anomaly in the record is completely open to speculation.

Pass $3(14: 00 \mathrm{~h} 08 / 20 / 71$ - 11:00 h 08/21/71) - The third pass encompassed a detailed mapping of the coastal region west of Cabo Frio; the surface temperature and salinity distributions are presented in Figures 6-7.

The minimum of surface temperature $\left(\mathrm{T}<16^{\circ} \mathrm{C}\right)$, together with an associated inflexion in the surface salinity ( $>35.6 \%$ ) distribution, appears to have centred on Saquarema Point (a small coastal protuberance hardly meriting the designation point). The phenomenon at this stage, is now clearly identifiable as upwelling.

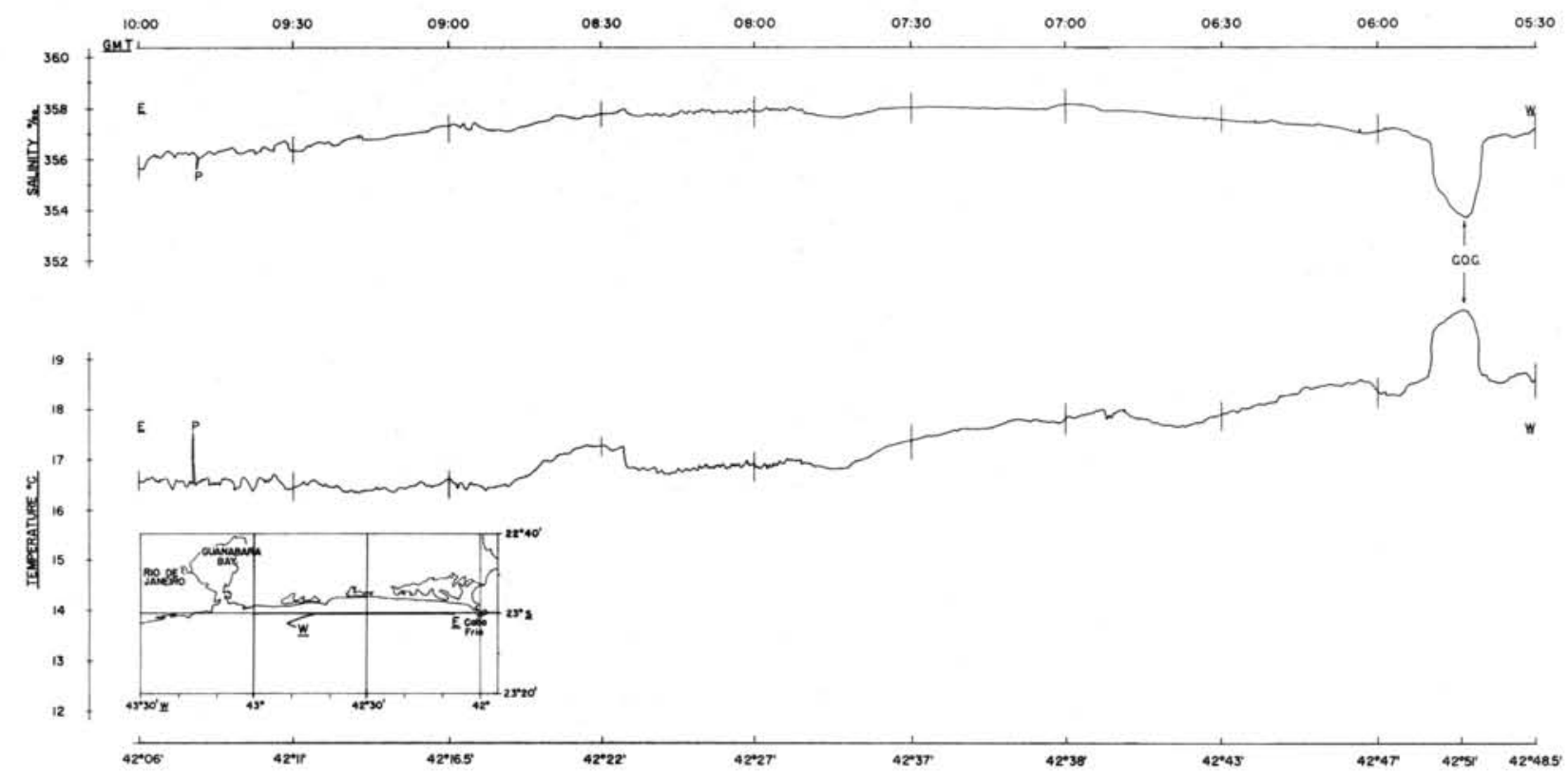

Fig. 5 - Temperature and salinity traces on the surface (pass 2, section 2). 


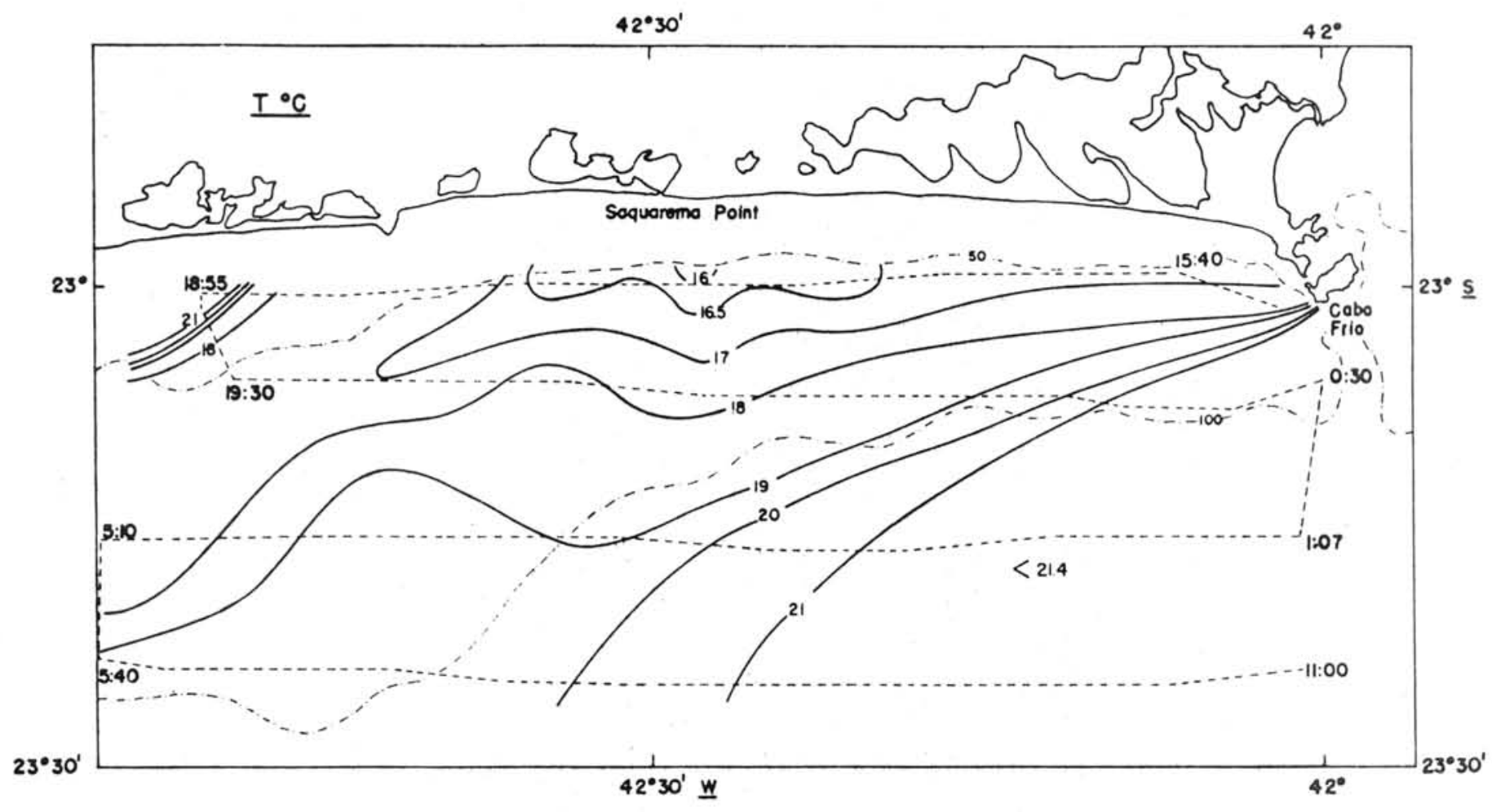

Fig. 6 - Temperature distribution on the surface (pass 3).

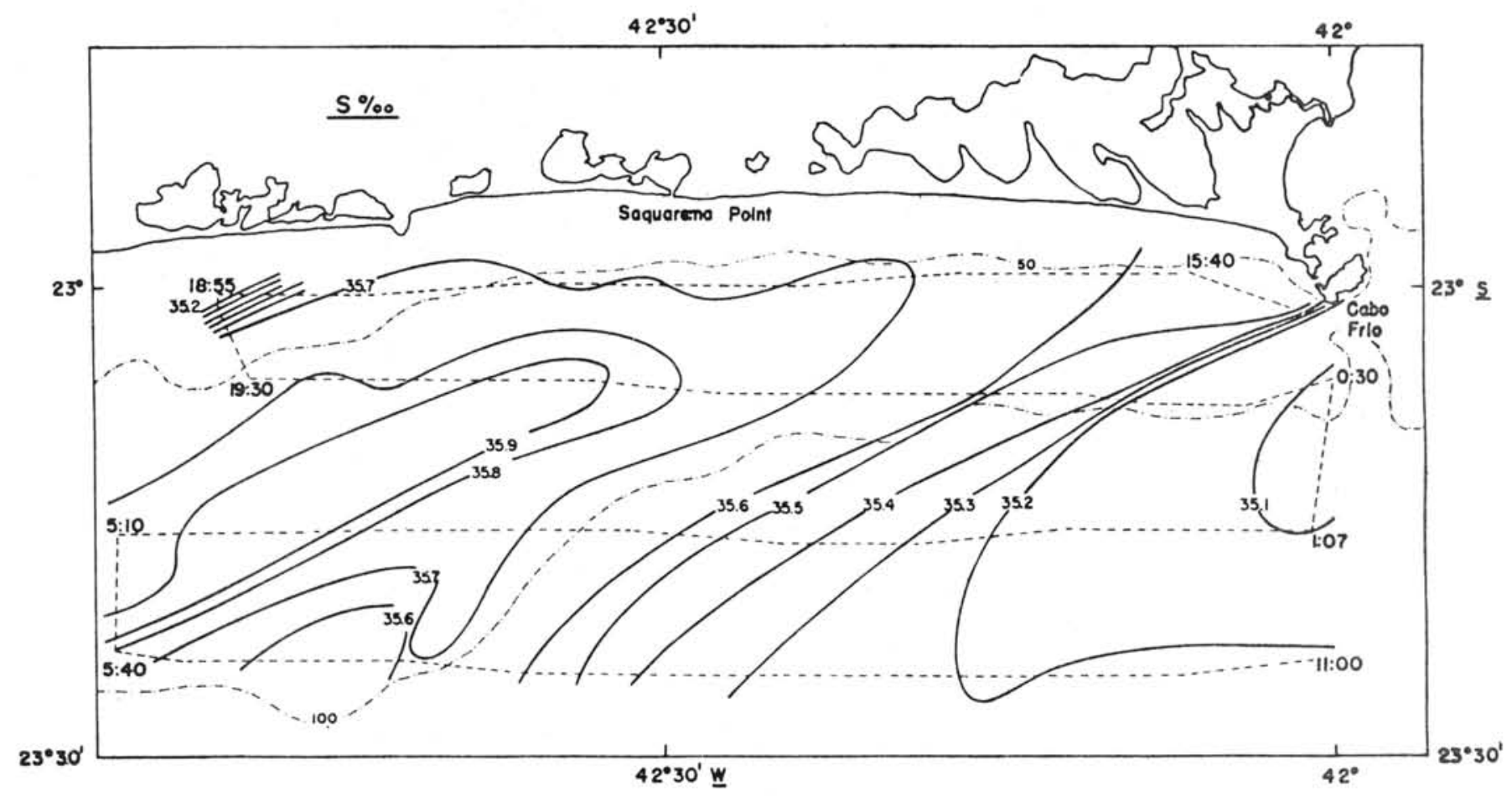

Fig. ? - Salinity distribution on the surface (pass 3). 
In the east of the region the original coastal-type water mass $\left(\mathrm{T}>21^{\circ} \mathrm{C}\right.$; $\mathrm{S}<35.2 \%$ o) still exists, presumably flowing south-easterly. A similar water-mass is found in the extreme west of the region close to the coast.

The assumed SW flow of warm and less saline water past Cabo Frio $\left(23^{\circ} 30^{\prime} \mathrm{S} ; 042^{\circ} 00^{\prime} \mathrm{W}\right)$ causes the maximum temperature and salinity gradients to localize at the cape (Cabo Frio), although the centre of upwelling has now shifted further west (compare Figs 4-5 of Pass 2). The temperature and salinity gradients decrease almost linearly in a WSW direction in what might be a classical entrainment "fan".

An extensive tongue-1ike region of salinity higher than $35.9 \% / 00$ (Fig. 7) is associated with surface temperatures of $18-19^{\circ} \mathrm{C}$, situated between the upwelling region and the lighter coastal-type water previous 1 y mentioned.

Pass 4(23:20 h 08/24/71 - 10:30 h 08/25/71) - Between Pass 3 and 4 two networks of hydrographic stations were effected, during which meteorological data was also collected.

Pass 4 shows a we11 developed tongue of upwelled water centred on Saquarema Point, flowing out to the SW with low temperatures $\left(14.9^{\circ} \mathrm{C}<\mathrm{T}<16^{\circ} \mathrm{C}\right)$ extending more than $30 \mathrm{~nm}$ out to sea (Fig. 8).

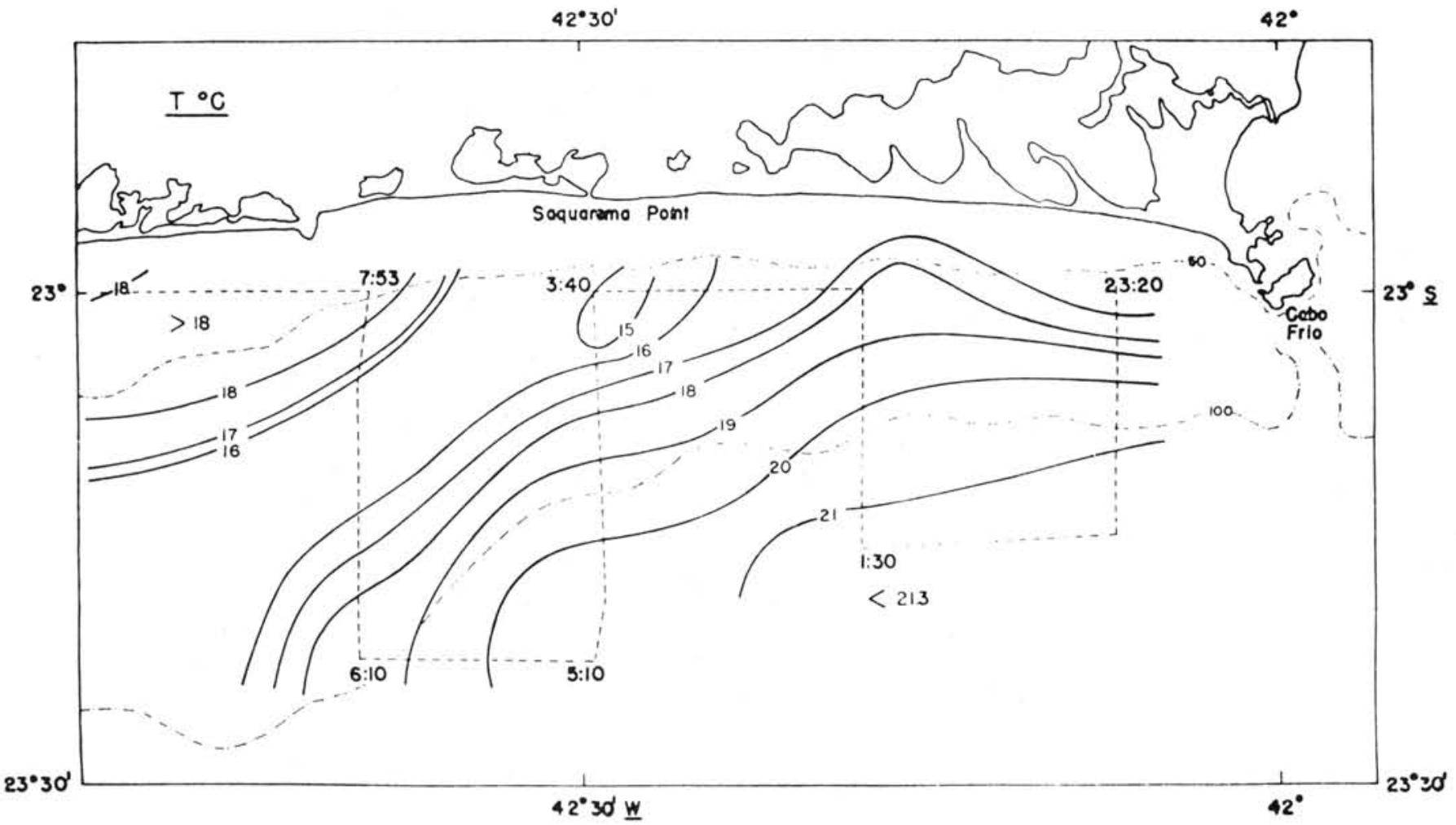

Fig. 8 - Temperature distribution on the surface (pass 4 ). 
The high salinity core, previously described in Pass 3 , appears to have dislodged to the east (Fig. 9) counter to the wind direction at an average speed of $1 / 4$ knot. The translation of this core may be associated with the general weakening of the temperature and salinity gradients in the west of the region.

The water mass in the east of the region $\left(18^{\circ} \mathrm{C}<\mathrm{T}<19^{\circ} \mathrm{C}\right.$; and $35.3 \% 0<\mathrm{S}<35.5 \%$ seemed to be formed by the mixing of the previous coasta1-type water $\left(\mathrm{T}>21^{\circ} \mathrm{C} ; \mathrm{S}<35.2^{\circ} \% \mathrm{o}\right)$ with an upwel1ing water mass $\left(\mathrm{T}=15^{\circ} \mathrm{C} ; \mathrm{S}=35.6^{\circ} / 00\right)$. The remnants of the 1 atter water mass appear as an isolated region of higher salinity ( $\left.=35.6^{\circ} / 00\right)$ in the "tail" of the upwelled water (Fig. 9). Such mixing would reinforce the idea that an eastern current flows opposing the wind direction.

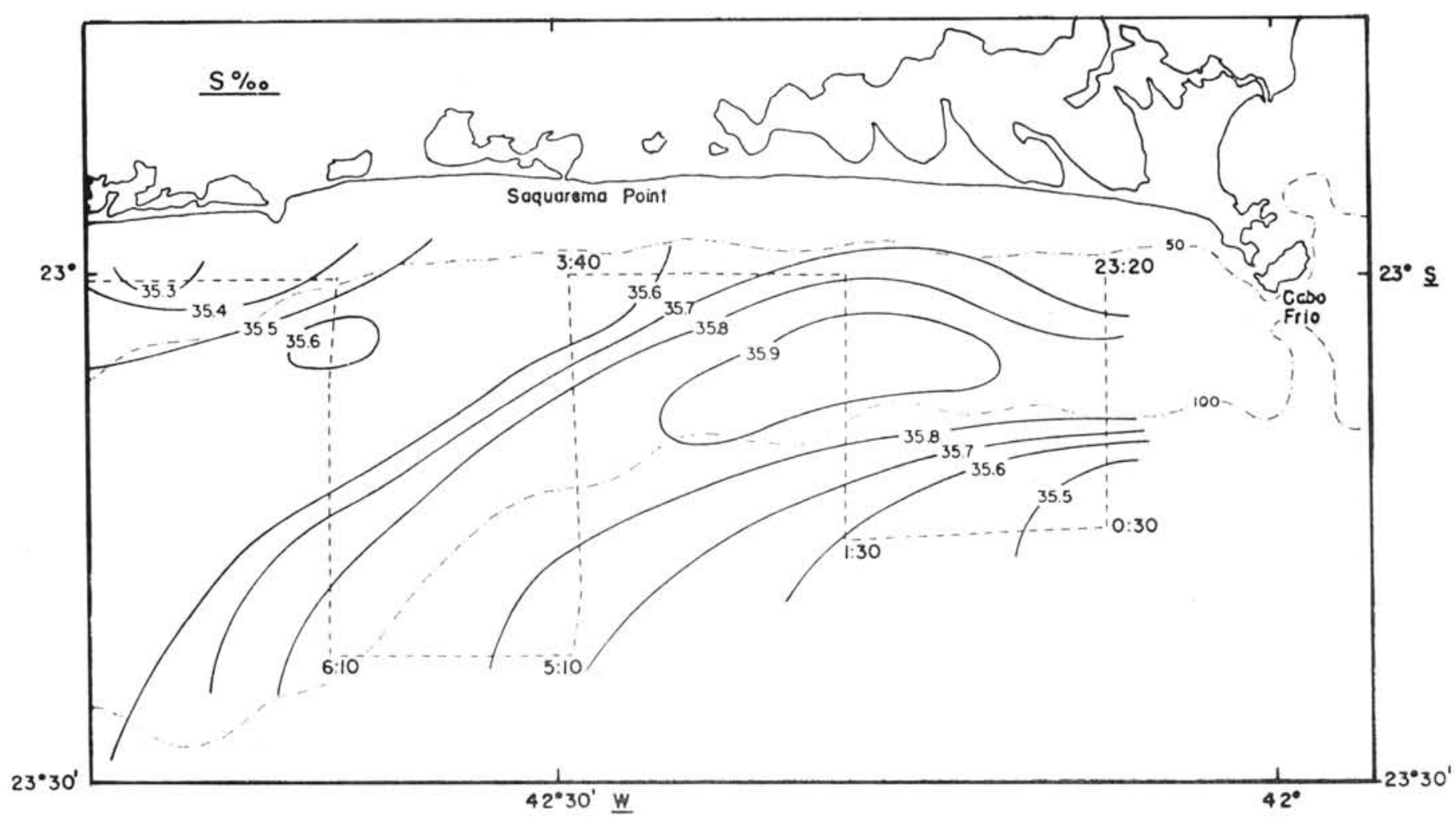

Fig. 9 - Salinity distribution on the surface (pass 4) 
c. WIND-FIELD

The observed wind-field during the period of hydrographic stations $(08 / 21-08 / 24)$ is presented in Figures 10-11, from which in can be seen that the winds offshore are stronger and "backed" in direction with respect to the winds inshore.

Verification of the reality of this spatial effect was obtained by comparison with data from an industrial meteorological station, Companhia Nacional de Alcalis, situated on the coast a little west of Cabo Frio. Time series results from this station of wind-speed and direction together with surface water temperature are presented in Figure 12. This figure shows the time variation of surface temperature due to the development of the upwelling process. The time lapse between the onset $N E$ winds $(>5 \mathrm{~m} / \mathrm{s})$ and the first appearence of colder upwelling water is about 24 hours.

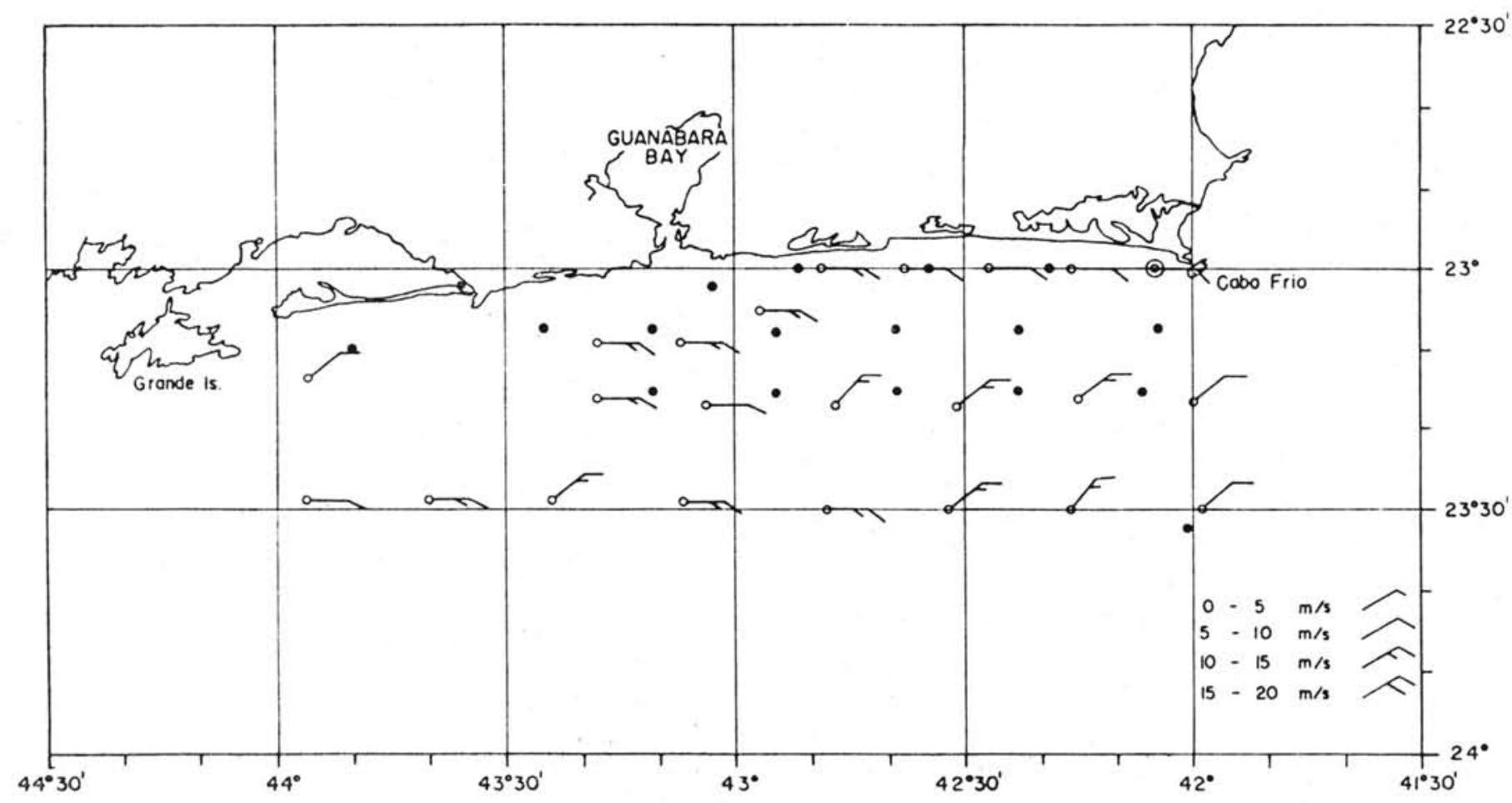

Fig. 10 - Wind field distribution (no. 1). 


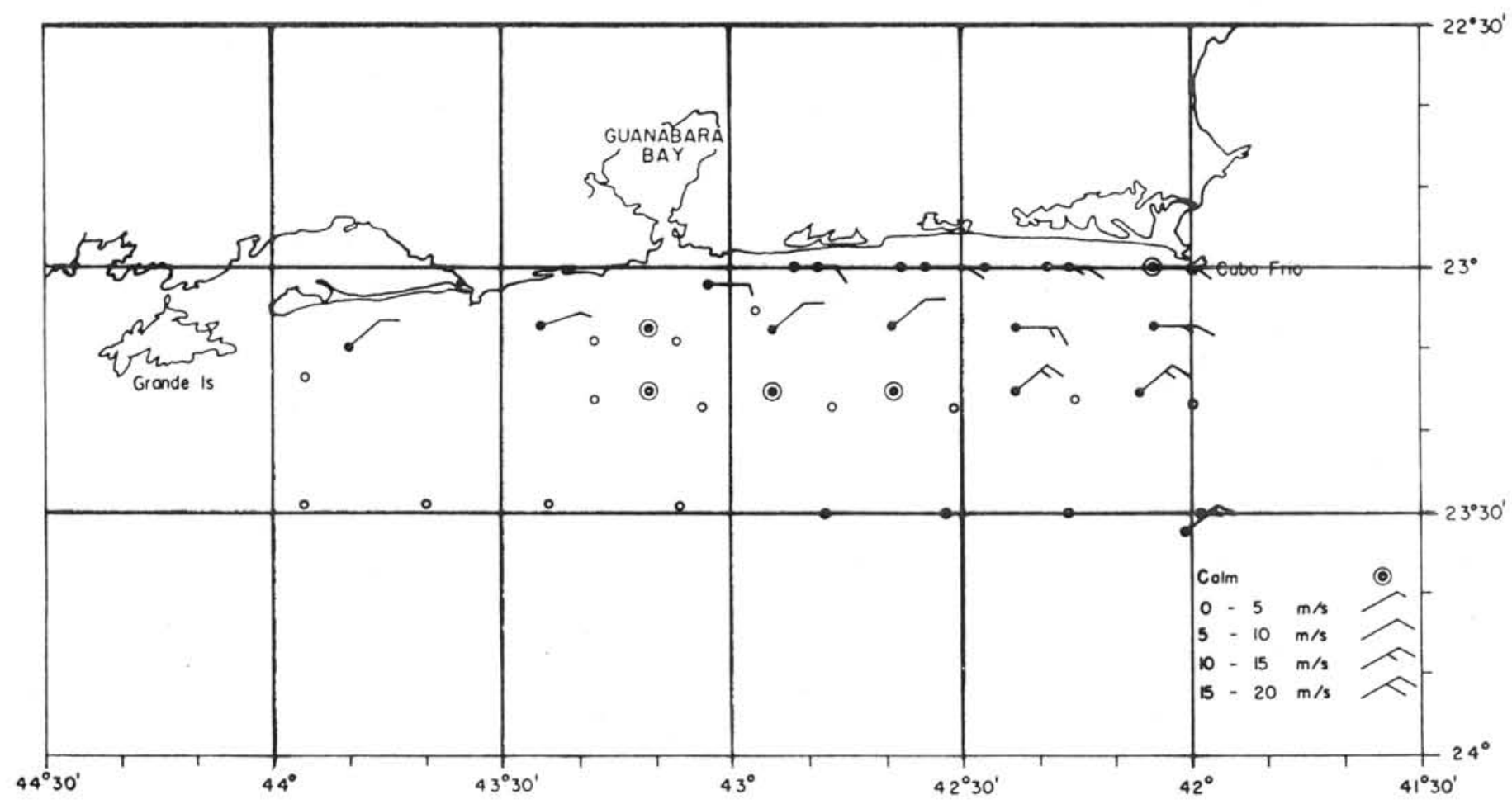

Fig. 11 - Wind field distribution (no. 2).
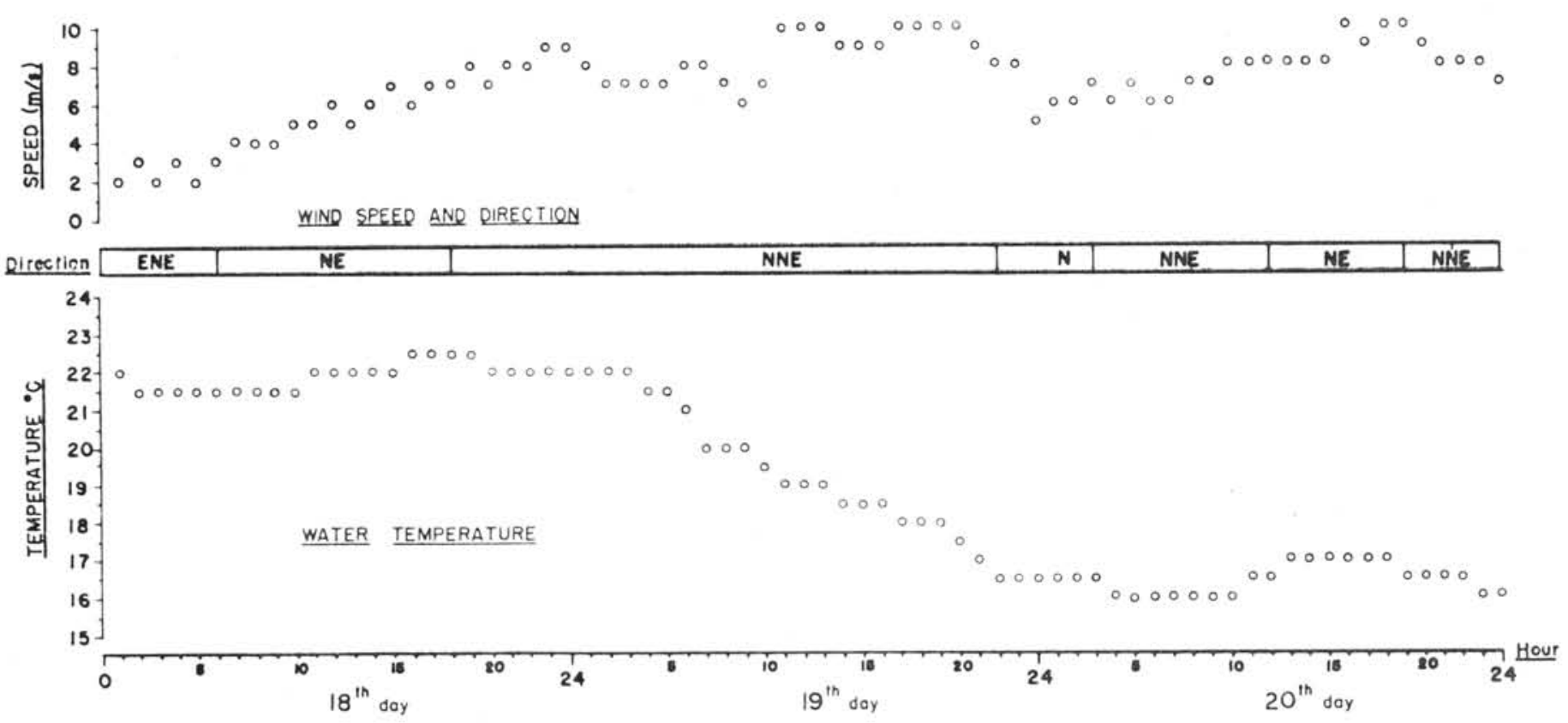

TIME GMT $(-3 h)$ AUGUST 1971

Fig. 12 - Local time variations of the wind and water temperature at Cabo Frio. 


\section{S CUS S I ON}

Several interesting points in the present data merit discussion. The most remarkable is the rapidity of the upwelling process. Normally at least a half pendulum day (approximately 30 hours for latitude $23^{\circ}$ ) is required, for a quasi-steady state wind drift current to form after the onset of the generating winds (Ekman, 1905). However, as seen from the local variation at Cabo Frio (Fig. 12) the surface temperature reached its minimum value, $\simeq 24$ hours after the first signs of upwelling had appeared. On the spatial scale, the first indication of the upwelling appeared at progressively later times and further shore the surface was sampled (Figs 4-5).

Such rapidity of upwelling is attributed to the presence of sources of cold-saline Subtropical Shelf Water (STSW), almost always present in the form of elongated cores, upon the continental shelf (Emílsson, 1961; Mascarenhas, Miranda \& Rock, 1971; Almeida, Mascarenhas \& Ikeda, 1971). Thus when favourable conditions of divergence occur, the surface indications of upwelling develop rapidiy.

A rapid analysis of the orientation of these cores of STSW, from the hydrographic data, indicates a flow in the wNW direction towards saquarema Point. An average velocity for the advancement of these cores over the continental shelf can be estimated from the displacement of isotherms as 0.35 knots. This estimate, due to the additional effects of horizontal mixing, could be slightly higher or lower. The surface outflow in the wSW direction is presumably at a comparable speed (not readily estimable). Furthermore it is interesting to note that the subsurface inflow and the surface outflow are incident at the same angle to the coast $\left(\simeq 50^{\circ}\right)$.

The spatial development and variation of the upwelling process is no-less surprising. The upwelling minimum intensifies at about $30 \mathrm{~nm}$ to the west of Cabo Frio (Saquarema Point), as well as a core of high salinity water moving upwind at an average speed of $1 / 4$ knot towards Cabo Frio. The existence of such a current has been inferred previously (Mascarenhas, Miranda \& Rock, op. cit.), but this is the first observation of the phenomenon based on quasisynoptic field distribution.

If upwelling phenomenon is explained on basis of an unilateral coastal divergence induced by an uniform wind field, as in the case of the Ekman's classical theory, then the upwind surface current will be an anomaly. Nevertheless, as can be seen (Figs 10-11) the hypothesis of a uniform wind field does not fit in with the reality and, correspondingly, the surface windstress is also non-uniform. Therefore, the horizontal divergence within the mixed-layer may be, to a good approximation, attributed to the horizontal divergence of the induced wind drift current (Charney, 1955).

The divergence in the wind-field can be ascribed to the differences in frictional roughness experienced by the wind blowing over 1 and and sea paths. 
Furthermore, the divergence in the wind-stress field may be accentuated by differences in fetch of the wind-field, producing waves of different heights and thus a surface of differing hydrodinamic roughness.

Accordingly, apart from the divergence immediately near the coast, one can expect a secondary divergence region extending from the Cabo Frio, in a WSW direction. Due to the restraining presence of the Brazil Current and the classical slope current, this secondary divergence leads to the generation of an upwind moving current between the major currents. Its driving mechanism is thought to be a combination of the wind-stress vorticity and pressure gradient forces.

\section{CONCLUSION}

The use of a continuous sea surface temperature and salinity sampler has proved an invaluable tool for the investigation of the upwelling phenomenon.

However, the utilization of a device for mapping in two dimension on $1 y$ serves to emphasize our lack of knowledge of upwelling which is threedimensional and a time-variant process.

Besides wind-force, the cold cores of STSW on the continental shelf play a critical role in the upwelling process. Furthermore the participation of the Brazil Current in the dynamics of the upwe1ling phenomenon is a completely unknown factor.

Finally, there is an urgent need for continuous automatic measurement of oceanographic and meteorological parameters in the area to provide a timehistory of the upwelling phenomenon, before the measuring vessel enters the area and after it has left. So the precise mechanism of the upwelling can be established, and perhaps a suitable predictor technique developed.

RESUMO

A apresentação cronológica quase-sinótica da distribuição da temperatura e da salinidade de superfície mostrou a ausência e estágios do desenvolvimento do fenômeno de ressurgência na região costeira a oeste de Cabo Frio. o vento, com direção variável entre $E$ e $N E$ e com velocidade máxima de 30 nós $(\simeq 15 \mathrm{~m} / \mathrm{s})$, foi considerado como o seu principal agente gerador.

Durante a evolução do fenômeno de ressurgência observou-se um núcleo de a1ta salinidade ( $\simeq 35.9 \%$ fluindo contra o vento com uma velocidade média de $1 / 4$ de nó. A causa desse movimento foi qualitativamente explicada como um efeito dinâmico induzido pela não uniformidade do campo de vento. 
A variação local observada na costa e a amostragem espacial na região costeira, mostraram que a primeira influência da massa de água ressurgida aparece contígua à costa e se distribui quase uniformemente de Cabo Frio até a Ponta de Saquarema. Contudo, no que julgamos ser um estágio final quase estacionário, o núcleo de ressurgência identificado pelo mínimo de temperatura de superfície, se localizava na Ponta de Saquarema com sua influência sendo observada na direção sudoeste e a mais de $30 \mathrm{mn}$ de distância à costa.

\section{ACKNOWLE DGMENTS}

The authors wish to express their thanks to all members of the Instituto Oceanográfico da Universidade de São Paulo, who made this publication possible. We are very much indebted to Instituto de Pesquisas Espaciais (INPE) who provided the electronic equipment for the quasi-synoptic measurements and the Companhia Nacional de Alcalis, for putting at our disposal the meteorological data of their meteorological station. Thanks are also due to Mr. Argeo Magliocca for a critical reading of the manuscript.

\section{B IBLIOGRAPHY}

ALMEIDA, E.G., MASCARENHAS Jr., A.S. \& IKEDA, Y. 1971. Pre1iminary results and analysis of the Mission SEREMAR II. Data Report 14/ONU/INPE, 73 p.

CHARNEY, J.C. 1955. The generation of ocean currents by wind. J. mar. Res., 14 (4): 477-498.

EKMAN, V.W. 1905. On the influence of the earth's rotation on ocean currents. Ark. Mat. Astr. Fys., 2 (11).

EMÍLSSON, I. 1959. Alguns aspectos físicos e químicos das àguas marinhas brasileiras. Ciênc. Cult., S Paulo, 11 (2):44-54.

1961. The shelf and coastal waters of southern Brazil. Bolm Inst. oceanogr., S Pau10, 11 (2): 101-112.

MAGLIOCCA, A. \& MIRANDA, L.B. On the occurrence of upwelling west of Cabo Frio (Brazil) in February 1971. (In press).

MASCARENHAS Jr., A.S., MIRANDA, L.B. \& ROCK, N.J. 1971. A study of oceanographic conditions in the region of Cabo Frio. In: Cost low Jr., J.D., ed. - Fertility of the sea. New York, Gordon \& Breach, vol. 1, p. 285308 .

SILVA, P.C.M. da 1960. Estudo das condições oceanográficas sôbre a plataforma continental, entre Cabo Frio e Vitória, durante o outono (abri1maio). Anais hidrogr., Rio de J., 18:261-289.

cal \& RODRIGUES, R.F. 1966. Modificaçoes na estrutura vertical das águas sôbre a borda da plataforma continental por influência do vento. Notas téc. Inst. Pesqui. Marinha, Rio de J., (35):1-6. 